\title{
Pesticide resurrection
}

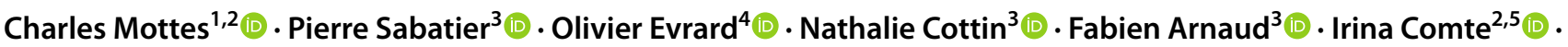

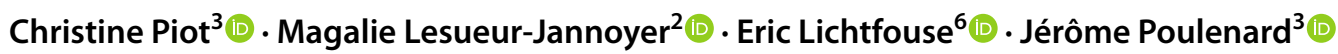

Published online: 30 October 2021

(c) The Author(s), under exclusive licence to Springer Nature Switzerland AG 2021, corrected publication 2022

The actual health risk and associated diseases induced by the presence of pesticides and other organic pollutants in most environmental media worldwide are largely underestimated because current analytical methods measure only the extractable fraction of the pollutant, whereas there is now ample evidence that a large part of pollutants are trapped as bound residues in complex organo-mineral matrixes, and are thus unanalyzable by current tools. Once trapped, pollutants can be stored for long periods, then released in the biosphere upon suitable conditions such as soil erosion and climate change. This 'resurrection' and underlying mechanisms of trapping, storage and release are poorly known. Here we discuss the limit of knowledge on bound pollutants and their later release, with examples of organochlorines in glaciers, vineyards and banana plantations. Unexpectedly, soil application of a modern pesticide such as glyphosate, can lead to the resurrection of ancient, actually banned pesticides such as chlordecone and dichlorodiphenyltrichloroethane (DDT) (Fig. 1).

\footnotetext{
Charles Mottes

charles.mottes@cirad.fr

Pierre Sabatier

pierre.sabatier@univ-smb.fr

Olivier Evrard

olivier.evrard@1sce.ipsl.fr

Nathalie Cottin

nathalie.cottin@univ-smb.fr

Fabien Arnaud

fabien.arnaud@univ-smb.fr

Irina Comte

irina.comte@cirad.fr

Christine Piot

christine.piot@univ-smb.fr

Magalie Lesueur-Jannoyer magalie.jannoyer@cirad.fr

Eric Lichtfouse

eric.lichtfouse@gmail.com
}

\section{Silent spring}

The Silent spring book by Rachel Carson, first published in 1962, marks the start of public awareness of global pollution (Carson 2002; Hallmann et al. 2014). Pesticides and herbicides are used to prevent pests and weeds to damage crops. In 2018, the global agricultural use of pesticides has been estimated to exceed 4 million tons of active ingredients (FAO 2020). This massive use has led to a global soil contamination, as illustrated by the widespread pollution of soils in Europe (Silva et al. 2019). The discovery of endocrinedisrupting chemicals has also induced serious concerns for public health (Diamanti-Kandarakis et al. 2009).

\section{Pollution ignores borders}

Pollution is not limited to the location where pesticides are applied. Indeed, pesticides are partly transferred to other media, e.g., water and air, then carried to other locations. Pesticides are found in remote and supposedly pristine regions of the Earth. For instance, in the 1960's, researchers detected pesticides in Antarctica, which means that contamination has spread through air and water to the most

Jérôme Poulenard

jerome.poulenard@univ-smb.fr

1 UPR HortSys, 97455 Saint-Pierre, La Réunion, France

2 HortSys, Geco, Univ Montpellier, CIRAD, 34398 Montpellier, France

3 Univ Savoie Mont Blanc, CNRS, Edytem, 73000 Chambéry, France

4 LSCE/IPSL, Univ. Paris-Saclay, UVSQ, CEA, CNRS, 91191 Gif-sur-Yvette, France

5 Cirad, UPR GECO, Capesterre-Belle-Eau, 97130 Guadeloupe, France

6 Aix Marseille Univ, CNRS, IRD, INRAE, CEREGE, Aix-en-Provence, France 


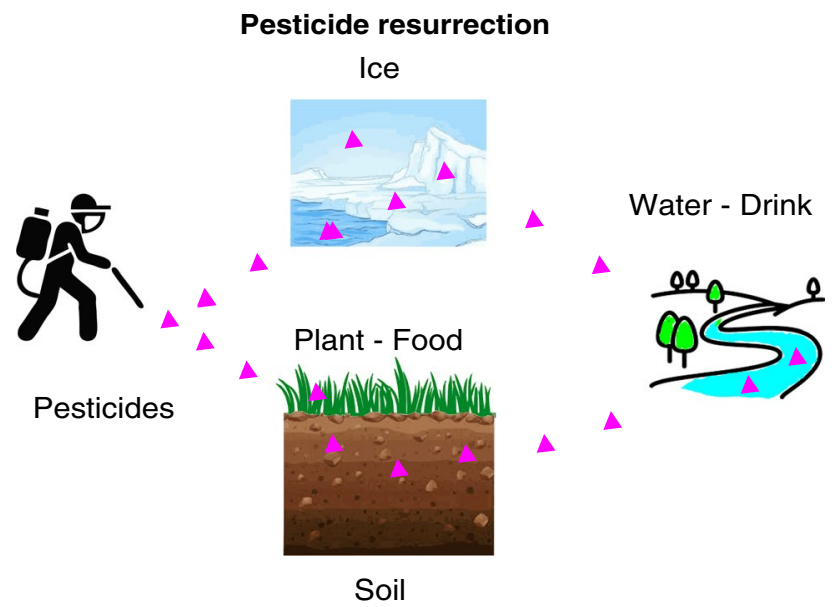

Fig. 1 Pesticides and other pollutants are trapped in soils, ice and other environmental media by unknown mechanisms for unknown time periods, then are eventually released in the biosphere, thus inducing a second toxic event

remote and isolated parts of the Earth (Tatton and Ruzicka 1967; Potapowicz et al. 2020). Scientists have then realized that any ecosystem compartment is not closed, and that pollutants can be transferred from one compartment to another under suitable conditions. Accordingly, cropped and pastured soils are of particular concern because soils are intimately connected to surface water, groundwater, atmosphere, wildlife and even seawater (Vereecken 2005; Chang et al. 2011; Banwart et al. 2013; Della Rossa et al. 2017; Mottes et al. 2019).

\section{Dormant pollution}

Soils are also the main support for food production systems and other ecosystem services (Dominati et al. 2010). Once a pesticide molecule enters a soil, many possible phenomena can happen: the pesticide can be immobilized in minerals or organic matter, degraded by bacteria, and transferred to water, air or the pest target. Yet the underlying mechanisms are still poorly known (Lichtfouse 1997). In particular, there is few knowledge on pollutant 'resurrection', a process by which a pollutant stays encapsulated in the soil for a certain time-may be years or more?-then is released into the biosphere, inducing another toxic event. This soil remobilization of a pesticide has been suspected following the detection of substances that have been banned since a long time, e.g. dichlorodiphenyltrichloroethane (DDT) in French vineyards, atrazine in corn and sugarcane cropped areas, and chlordecone in banana cropped area (Dalton et al. 2014; Sabatier et al. 2014; Lesueur Jannoyer et al. 2016). There is now ample evidence for pollution of water and sediments from water-monitoring systems in agricultural areas
(Konstantinou et al. 2006; Stehle and Schulz 2015; Mottes et al. 2017; de Souza et al. 2020; Didoné et al. 2021).

\section{Pesticide toxicity}

Pesticide pollution does not disappear with the ban of pesticides. For example, DDT, chlordecone and atrazine have persisted in ecosystems at least 30 years after their ban. Farmers and population are thus exposed to secondary waves of pesticides by direct exposure, e.g., in air, when drinking polluted water or eating contaminated food (Aktar et al. 2009; Fantke et al. 2011; Toan et al. 2013; Clostre et al. 2014, 2017; Damalas and Koutroubas 2016). Pesticide residues in food and drinking water represent a serious threat to public health. Indeed, residues can compromise neuroendocrine development in unborn and newborn children and lead to chronic kidney diseases in the later life. Recent studies have also shown the influence of pesticides on breast cancers, and their toxicity for non-targeted organisms such as human populations (Gill et al. 2018; Singh et al. 2018; Xu et al. 2018; Kass et al. 2020). Biodiversity is also altered after pesticide application, as shown by the changes in arthropod behavior (de Jong et al. 2008; Brittain et al. 2010; Geiger et al. 2010; Ewald et al. 2015). Soil also influences the transport of pesticides to pollinators during tillage and bee queen hibernation in soils (Raine 2018). Biologically-significant concentrations of banned organochlorine pesticides (OCPs) still continue to be reported in wildlife, and are of particular concern for the highest trophic levels due the process of biomagnification (Humphries et al. 2021).

\section{Bound residues}

In 1989, during one day, we extracted three times soil samples that have been incubated with ${ }^{14} \mathrm{C}$-atrazine. As expected, the radioactivity levels of the extract decreased in the second and third extracts. But, surprizingly, when we did a fourth extraction the next day, the extract radioactivity was higher than the previous extract. Something was going on here, probably a change in soil conditions overnight, which induced the release of bound atrazine (personnal communication from Prof. Michel Schiavon in 1996).

Bound residues refer to compounds, unchanged or partly degraded, that are trapped in complex media, e.g., soil, sediment, food and living organisms, by various mechanisms such as chemical binding or physical encapsulation. Binding mechanisms were first considered as pathways for the removal of chemicals - and their associated toxicity-from the biosphere (Karasali and Pavlidis 2021). However, actually many questions remain unanswered or partly answered about bound residues, for instance: 
- What are their chemical structure?

- How are they formed and trapped?

- What percentage of the applied compound is trapped?

- Are they partly degraded or not before trapping?

- To which compounds are they bound? How?

- How much time do they stay entrapped?

- Will they be released in the short or long run?

- Where do they go upon release?

- What are the conditions needed for their release?

- What is their toxicological impact?

Some control processes are known but the scientific community remains actually unable to clearly understand and quantify bound residues, notably due the limits of analytical methods. This is for instance the case for non-extractable residues, which are commonly observed by indirect methods, e.g., ${ }^{14} \mathrm{C}$ tracing and nuclear magnetic resonance (NMR), but are not unambiguously characterized at the molecular level because the solids in which they are trapped are too complex for current analytical tools. One of the consequences of this analytical limit is that it is actually impossible to determine the true concentration of a pesticide-or any organic compound-in a complex media because a part of this pesticide is bound and unanalyzable.

When pesticides are applied to soils, they form nonextractable residues, and a fraction of these residues, which may reach $70 \%$, is strongly bound to soil components, mainly to organic matter and clays (Barriuso et al. 2008; Woignier et al. 2012, 2019; Karasali and Pavlidis 2021). For most pesticides, the binding processes are not known, while the potential toxicity due to the presence of non-extractable pesticide residues is high (Gevao et al. 2000). Therefore, these hardly bound residues should be better taken into account to assess the environmental fate of pesticides (Schäffer et al. 2018). In addition, analytical methods should be developed to identify and quantify bound residues (Loeffler et al. 2020). For instance, molecular level ${ }^{13} \mathrm{C}$-tracing has allowed to evidence the occurrence of temporal pools of the same organic compound in various fractions of the same soil sample (Lichtfouse et al. 1998; Lichtfouse 1999, 2012). Moreover, cleavage of sedimentary matter with $\mathrm{Na}^{18} \mathrm{OH}$ has shown that DDT metabolites are bound to organic macromolecules (Kalathoor et al. 2015). A better knowledge of binding mechanisms would help to design remediation techniques such as extraction (Karasali and Pavlidis 2021).

Besides extraction, biological and chemical degradation are two other methods to remove pesticides from soil and wastewater, yet there is a lack of analytical methods and standards for quantifying degradation products (Andreu and Picó 2004). Typically, most published articles investigating pesticide 'degradation' in complex media are only measuring the remaining, extractable concentration of the parent molecule to measure a 'removal' percentage by substraction. Here, using the term 'degradation' is wrong if degradation products are not identified. Moreover, even after $100 \%$ removal of a pollutant-from the extractable fraction-a major part of the parent molecule may occur, unchanged or degraded, in the bound, unanalyzable residues. Similarly, even when the parent molecule is not detected anymore in the analyzable fraction, metabolites are still widely found, e.g., as deethylatrazine for atrazine, aminomethylphosphonic acid (AMPA) for glyphosate, dichlorodiphenyldichloroethylene (DDE) for DDT (Sabatier et al. 2014). Overall, a large fraction of pesticides and other organic pollutants is actually overlooked and most probably presents a higher toxicological risk, notably in the long run, than the risk assessed by current classical analysis.

\section{Pesticide resurrection}

Under suitable changing conditions, trapped pollutants may be released in the biosphere (Fig. 2). For example, ancient organochlorines trapped in Antarctica and Alpine glaciers may be released by ice melting in the context of climate change (Bettinetti et al. 2008; Schmid et al. 2011; Potapowicz et al. 2020). Climate seasonality is also a likely cause

\section{Resurrection of pesticides}
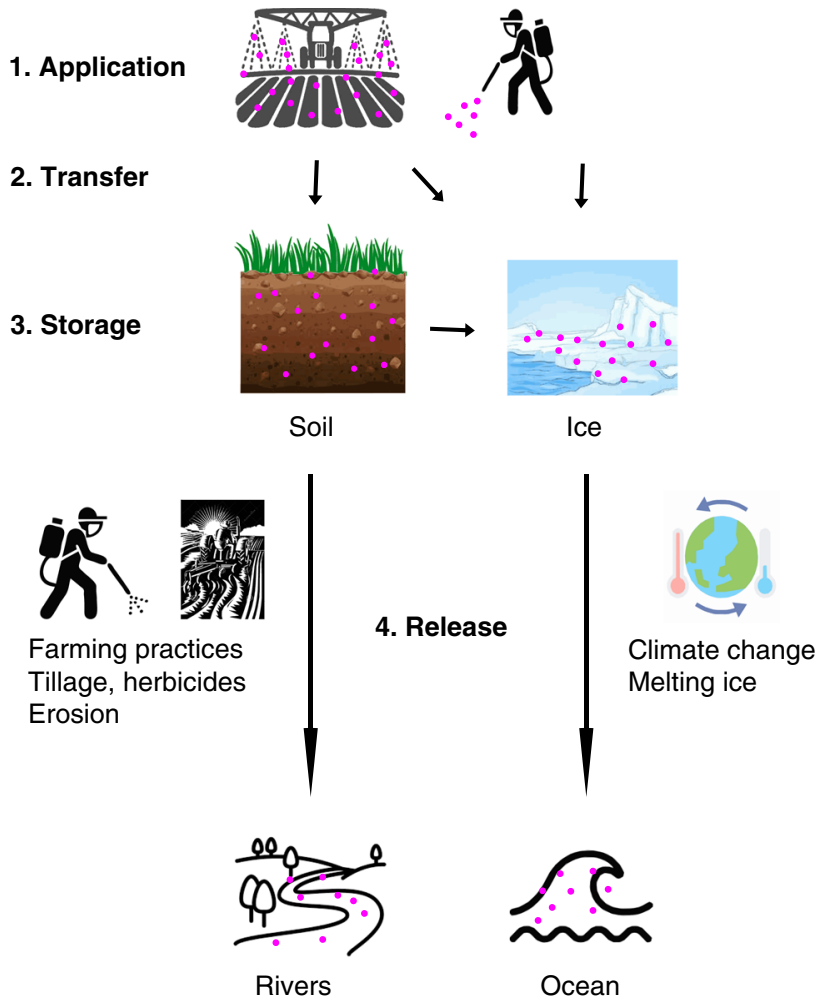

Fig. 2 Examples of pesticide resurrection pathways 
of pollutant release. For instance, modeling suggests that the Indian summer monsoon induces the revolatilization of soil-accumulated pollutants (Lammel et al. 2018). Another unexpected finding is the 'resurrection' of ancient pesticides that have been trapped in soils some time ago, e.g., DDT and chlordecone, by an actual application of a modern pesticide, e.g., glyphosate, a post-emergence herbicide, in French vineyards and banana plantations in the French West Indies (Sabatier et al. 2014, 2021). This implies that pesticides can be trapped, stored then released by glyphosate-induced soil erosion. This phenomenon is known as the soil memory effect (Foucher et al. 2020). More research is actually needed on the nature of bound pollutants, their degree of freedom and on the mechanisms ruling their trapping, storage, release and 'resurrected toxicity' in the biosphere. This should help to design remediation methods and farming practices that lessen health hazards.

\section{Farming practices}

In order to avoid pesticide resurrection, novel farming practices that no longer rely on the use of harmful pesticides should be designed with farmers (Fig. 3). For instance, in the French West Indies, chlordecone has been successfully replaced by pheromone traps, and by fallow management in banana cropping systems. Farmers are also better managing weeds by using cover crops, for instance, thus avoiding the use of herbicides. Tools and methods are being developed to help local stakeholders to coordinate their actions at the local scale to help reduce pesticide uses and the associated pollution (Della Rossa 2020). This demonstrates that innovation makes it possible to overcome environmental-related pesticide issues.

\section{References}

Aktar MW, Sengupta D, Chowdhury A (2009) Impact of pesticides use in agriculture: their benefits and hazards. Interdiscip Toxicol 2(1):1-12. https://doi.org/10.2478/v10102-009-0001-7

Andreu V, Picó Y (2004) Determination of pesticides and their degradation products in soil: critical review and comparison of methods. TrAC, Trends Anal Chem 23(10):772-789. https://doi.org/ 10.1016/j.trac.2004.07.008

Banwart SA, Chorover J, Gaillardet J, Sparks D, White T, Anderson S, Aufdenkampe A, Bernasconi S, Brantley S, Chadwick O (2013) Sustaining Earth's critical zone basic science and interdisciplinary solutions for global challenges. Univ. of Sheffield, Sheffield, UK

Barriuso E, Benoit P, Dubus IG (2008) Formation of pesticide nonextractable (Bound) residues in soil: magnitude, controlling factors and reversibility. Environ Sci Technol 42(6):1845-1854. https:// doi.org/10.1021/es7021736

Bettinetti R, Quadroni S, Galassi S, Bacchetta R, Bonardi L, Vailati $\mathrm{G}$ (2008) Is meltwater from Alpine glaciers a secondary DDT

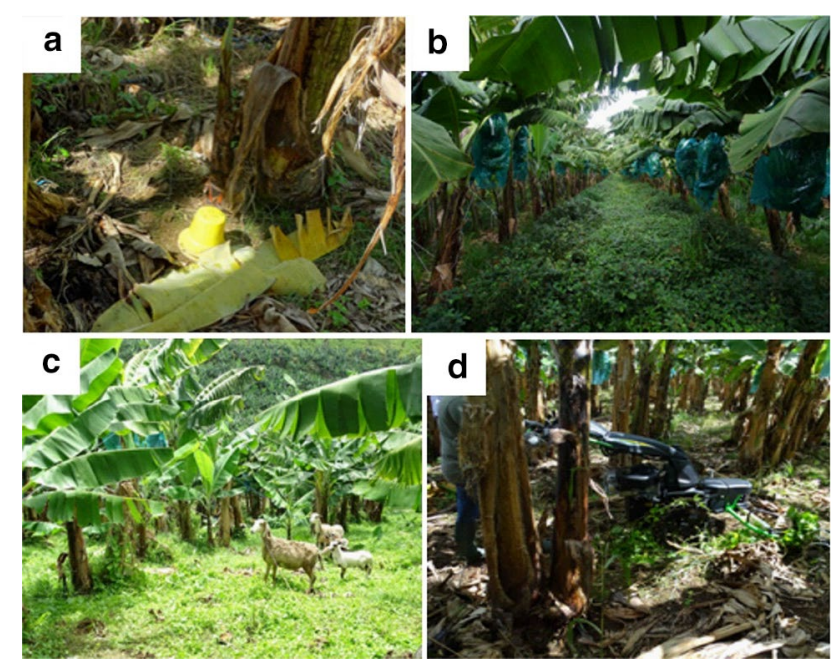

Fig. 3 Innovations developed to reduce pesticide application in the French West Indies. a) A pheromone trap has replaced chlordecone application in banana fields. b) A cover crop, Desmodium spp., is grown in a banana field to avoid herbicide application. c) A bananalivestock association reduces herbicide use and uses weed as sheep fodder. d) Weeds are removed by small mechanical tools, thus limiting herbicide application. Photography credits: Charles Mottes

source for lakes? Chemosphere 73(7):1027-1031. https://doi.org/ 10.1016/j.chemosphere.2008.08.017

Brittain CA, Vighi M, Bommarco R, Settele J, Potts SG (2010) Impacts of a pesticide on pollinator species richness at different spatial scales. Basic Appl Ecol 11(2):106-115. https://doi.org/10.1016/j. baae.2009.11.007

Carson R (2002) Silent spring, Houghton Mifflin Harcourt.

Chang FC, Simcik MF, Capel PD (2011) Occurrence and fate of the herbicide glyphosate and its degradate aminomethylphosphonic acid in the atmosphere. Environ Toxicol Chem 30(3):548-555. https://doi.org/10.1002/etc.431

Clostre F, Letourmy P, Turpin B, Carles C, Lesueur-Jannoyer M (2014) Soil type and growing conditions influence uptake and translocation of organochlorine (Chlordecone) by cucurbitaceae species. Water Air and Soil Pollut. https://doi.org/10.1007/ s11270-014-2153-0

Clostre F, Letourmy P, Lesueur-Jannoyer M (2017) Soil thresholds and a decision tool to manage food safety of crops grown in chlordecone polluted soil in the French West Indies. Environ Pollut 223:357-366. https://doi.org/10.1016/j.envpol.2017.01.032

Dalton RL, Pick FR, Boutin C, Saleem A (2014) Atrazine contamination at the watershed scale and environmental factors affecting sampling rates of the polar organic chemical integrative sampler (POCIS). Environ Pollut 189:134-142. https://doi.org/10.1016/j. envpol.2014.02.028

Damalas CA, Koutroubas SD (2016) Farmers' exposure to pesticides: toxicity types and ways of prevention. Toxics 4(1):1. https://doi. org/10.3390/toxics4010001

de Jong FMW, de Snoo GR, van de Zande JC (2008) Estimated nationwide effects of pesticide spray drift on terrestrial habitats in the Netherlands. J Environ Manage 86(4):721-730. https://doi.org/ 10.1016/j.jenvman.2006.12.031

de Souza RM, Seibert D, Quesada HB, de Jesus Bassetti F, FagundesKlen MR, Bergamasco R (2020) Occurrence, impacts and general aspects of pesticides in surface water: a review. Process Saf Environ Prot 135:22-37. https://doi.org/10.1016/j.psep.2019.12.035 
Della Rossa P, Jannoyer M, Mottes C, Plet J, Bazizi A, Arnaud L, Jestin A, Woignier T, Gaude J-M, Cattan P (2017) Linking current river pollution to historical pesticide use: insights for territorial management? Sci Total Environ 574:1232-1242. https://doi.org/ 10.1016/j.scitotenv.2016.07.065

Della Rossa P (2020) Conception collective d'organisations territoriales innovantes pour une évolution coordonnée de systèmes de production agricoles. Cas d'une réduction de la pollution herbicide d'une rivière en Martinique. Thèse de doctorat : Sciences agronomiques Thèse, Université Paris-Saclay.

Diamanti-Kandarakis E, Bourguignon J-P, Giudice LC, Hauser R, Prins GS, Soto AM, Zoeller RT, Gore AC (2009) Endocrine-disrupting chemicals: an endocrine society scientific statement. Endocr Rev 30(4):293-342. https://doi.org/10.1210/er.2009-0002

Didoné EJ, Minella JPG, Tiecher T, Zanella R, Prestes OD, Evrard $\mathrm{O}$ (2021) Mobilization and transport of pesticides with runoff and suspended sediment during flooding events in an agricultural catchment of Southern Brazil. Environ Sci Pollut Res 28(29):39370-39386. https://doi.org/10.1007/ s11356-021-13303-Z

Dominati E, Patterson M, Mackay A (2010) A framework for classifying and quantifying the natural capital and ecosystem services of soils. Ecol Econ 69(9):1858-1868. https://doi.org/10.1016/j. ecolecon.2010.05.002

Ewald JA, Wheatley CJ, Aebischer NJ, Moreby SJ, Duffield SJ, Crick HQ, Morecroft MB (2015) Influences of extreme weather, climate and pesticide use on invertebrates in cereal fields over 42 years. Glob Chang Biol 21(11):3931-3950. https://doi.org/10.1111/gcb. 13026

Fantke P, Charles R, Alencastro LFd, Friedrich R, Jolliet O (2011) Plant uptake of pesticides and human health: dynamic modeling of residues in wheat and ingestion intake. Chemosphere 85(10):1639-1647. https://doi.org/10.1016/j.chemosphere.2011. 08.030

FAO (2020) Pesticides Uses Statistics. Global, regional and country trends 1990-2018. FAOSTAT Analytical Brief Series. Rome, FAO. No 9.

Foucher A, Evrard O, Ficetola GF, Gielly L, Poulain J, Giguet-Covex C, Laceby JP, Salvador-Blanes S, Cerdan O, Poulenard J (2020) Persistence of environmental DNA in cultivated soils: implication of this memory effect for reconstructing the dynamics of land use and cover changes. Sci Rep 10(1):10502. https://doi.org/10.1038/ s41598-020-67452-1

Geiger F, Bengtsson J, Berendse F, Weisser WW, Emmerson M, Morales MB, Ceryngier P, Liira J, Tscharntke T, Winqvist C, Eggers S, Bommarco R, Pärt T, Bretagnolle V, Plantegenest M, Clement LW, Dennis C, Palmer C, Oñate JJ, Guerrero I, Hawro V, Aavik T, Thies C, Flohre A, Hänke S, Fischer C, Goedhart PW, Inchausti P (2010) Persistent negative effects of pesticides on biodiversity and biological control potential on European farmland. Basic Appl Ecol 11(2):97-105. https://doi.org/10.1016/j. baae.2009.12.001

Gevao B, Semple KT, Jones KC (2000) Bound pesticide residues in soils: a review. Environ Pollut 108(1):3-14. https://doi.org/10. 1016/S0269-7491(99)00197-9

Gill JPK, Sethi N, Mohan A, Datta S, Girdhar M (2018) Glyphosate toxicity for animals. Environ Chem Lett 16(2):401-426. https:// doi.org/10.1007/s10311-017-0689-0

Hallmann CA, Foppen RPB, van Turnhout CAM, de Kroon H, Jongejans E (2014) Declines in insectivorous birds are associated with high neonicotinoid concentrations. Nature 511(7509):341-343. https://doi.org/10.1038/nature13531

Humphries MS, Myburgh JG, Campbell R, Buah-Kwofie A, Combrink X (2021) Organochlorine pesticide bioaccumulation in wild Nile crocodile (Crocodylus niloticus) fat tissues: environmental influences on changing residue levels and contaminant profiles.
Sci Total Environ 753:9. https://doi.org/10.1016/j.scitotenv.2020. 142068

Kalathoor R, Zeiner M, Schmidt B, Schäffer A, Schwarzbauer J (2015) First evidence for covalent linkage of acidic metabolites of metalaxyl and DDT as non-extractable pesticide residues in soil and sediment. Environ Chem Lett 13(4):431-437. https://doi.org/10. 1007/s10311-015-0514-6

Karasali H and Pavlidis G (2021) Non-extractable Pesticide Residues in Soils. Sustainable Agriculture Reviews 47: Pesticide Occurrence, Analysis and Remediation Vol. 1 Biological Systems. In: Inamuddin, M. I. Ahamed and E. Lichtfouse (Eds.) Cham, Springer International Publishing. pp. 203-226.

Kass L, Gomez AL, Altamirano GA (2020) Relationship between agrochemical compounds and mammary gland development and breast cancer. Mol Cell Endocrinol 508:9. https://doi.org/10.1016/j.mce. 2020.110789

Konstantinou IK, Hela DG, Albanis TA (2006) The status of pesticide pollution in surface waters (rivers and lakes) of Greece. Part I. Review on occurrence and levels. Environ Pollut 141(3):555-570. https://doi.org/10.1016/j.envpol.2005.07.024

Lammel G, Degrendele C, Gunthe SS, Mu Q, Muthalagu A, Audy O, Biju CV, Kukucka P, Mulder MD, Octaviani M, Pribylova P, Shahpoury P, Stemmler I, Valsan AE (2018) Revolatilisation of soil-accumulated pollutants triggered by the summer monsoon in India. Atmos Chem Phys 18(15):11031-11040. https://doi.org/10. 5194/acp-18-11031-2018

Lesueur Jannoyer M, Cattan P, Woignier T, Clostre F (eds) (2016) Crisis management of chronic pollution: contaminated soil and human health. Boca Raton, États-Unis, CRC Press

Lichtfouse E (1997) Soil, a sponge for pollutants. Analusis 25(8):M16-M23

Lichtfouse E (1999) Temporal pools of individual organic substances in soil. Analusis 27(5):442-444

Lichtfouse E (2012) 13C-dating, the first method to calculate the relative age of molecular substance homologues in soil. Environ Chem Lett 10(1):97-103. https://doi.org/10.1007/s10311-011-0334-2

Lichtfouse E, Wehrung P, Albrecht P (1998) Plant wax n-alkanes trapped in soil humin by non-covalent bonds. Naturwissenschaften 85(9):449-452. https://doi.org/10.1007/s001140050529

Loeffler D, Hatz A, Albrecht D, Fligg M, Hogeback J, Ternes TA (2020) Determination of non-extractable residues in soils: towards a standardised approach. Environ Pollut 259:113826. https://doi. org/10.1016/j.envpol.2019.113826

Mottes C, Lesueur Jannoyer M, Le Bail M, Guene M, Carles C, Malezieux E (2017) Relationships between past and present pesticide applications and pollution at a watershed outlet: the case of a horticultural catchment in Martinique, French West Indies. Chemosphere 184:762-773. https://doi.org/10.1016/j.chemo sphere.2017.06.061

Mottes C, Deffontaines L, Charlier JB, Comte I, Della Rossa P, Lesueur-Jannoyer M, Woignier T, Adele G, Tailame A-L, Arnaud L, Plet J, Rangon L, Bricquet J-P, Cattan P (2019) Spatiotemporal variability of water pollution by chlordecone at the watershed scale: what insights for the management of polluted territories? Environ Sci Pollut Res. https://doi.org/10.1007/ s11356-019-06247-y

Potapowicz J, Lambropoulou D, Nannou C, Kozioł K, Polkowska Ż (2020) Occurrences, sources, and transport of organochlorine pesticides in the aquatic environment of Antarctica. Sci Total Environ 735:139475. https://doi.org/10.1016/j.scitotenv.2020.139475

Raine NE (2018) A systemic problem with pesticides. Nature 561(7721):40-41. https://doi.org/10.1038/d41586-018-05917-0

Sabatier P, Poulenard J, Fanget B, Reyss J-L, Develle A-L, Wilhelm B, Ployon E, Pignol C, Naffrechoux E, Dorioz J-M, Montuelle B, Arnaud F (2014) Long-term relationships among pesticide 
applications, mobility, and soil erosion in a vineyard watershed. Proc Natl Acad Sci. https://doi.org/10.1073/pnas.1411512111

Sabatier P, Mottes C, Cottin N, Evrard O, Comte I, Piot C, Gay B, Arnaud F, Lefevre I, Develle A-L, Deffontaines L, Plet J, LesueurJannoyer M, Poulenard J (2021) Evidence of chlordecone resurrection by glyphosate in French West Indies. Environ Sci Technol. https://doi.org/10.1021/acs.est.0c05207

Schäffer A, Kästner M, Trapp S (2018) A unified approach for including non-extractable residues (NER) of chemicals and pesticides in the assessment of persistence. Environ Sci Eur 30(1):51. https:// doi.org/10.1186/s12302-018-0181-x

Schmid P, Bogdal C, Blüthgen N, Anselmetti FS, Zwyssig A, Hungerbühler K (2011) The missing piece: sediment records in remote mountain lakes confirm glaciers being secondary sources of persistent organic pollutants. Environ Sci Technol 45(1):203-208. https://doi.org/10.1021/es1028052

Silva V, Mol HGJ, Zomer P, Tienstra M, Ritsema CJ, Geissen V (2019) Pesticide residues in European agricultural soils-a hidden reality unfolded. Sci Total Environ 653:1532-1545. https://doi.org/10. 1016/j.scitotenv.2018.10.441

Singh S, Kumar V, Chauhan A, Datta S, Wani AB, Singh N, Singh J (2018) Toxicity, degradation and analysis of the herbicide atrazine. Environ Chem Lett 16(1):211-237. https://doi.org/10.1007/ s10311-017-0665-8

Stehle S, Schulz R (2015) Agricultural insecticides threaten surface waters at the global scale. Proc Natl Acad Sci USA 112(18):5750 5755. https://doi.org/10.1073/pnas.1500232112
Tatton JOG, Ruzicka JHA (1967) Organochlorine pesticides in Antarctica. Nature 215(5099):346-348. https://doi.org/10.1038/21534 $6 \mathrm{a} 0$

Toan PV, Sebesvari Z, Bläsing M, Rosendahl I, Renaud FG (2013) Pesticide management and their residues in sediments and surface and drinking water in the Mekong Delta, Vietnam. Sci Total Environ 452-453:28-39. https://doi.org/10.1016/j.scitotenv.2013.02.026

Vereecken H (2005) Mobility and leaching of glyphosate: a review. Pest Manag Sci 61(12):1139-1151. https://doi.org/10.1002/ps.1122

Woignier T, Clostre F, Macarie H, Jannoyer M (2012) Chlordecone retention in the fractal structure of volcanic clay. J Hazard Mater 241-242:224-230. https://doi.org/10.1016/j.jhazmat.2012.09.034

Woignier T, Rangon L, Clostre F, Mottes C, Cattan P, Primera J, Jannoyer M (2019) Physical limitation of pesticides (chlordecone) decontamination in volcanic soils: fractal approach and numerical simulation. Environ Sci Pollut Res. https://doi.org/10.1007/ s11356-019-05899-0

Xu X, Nie S, Ding H, Hou FF (2018) Environmental pollution and kidney diseases. Nat Rev Nephrol 14(5):313-324. https://doi.org/ 10.1038/nrneph.2018.11

Publisher's Note Springer Nature remains neutral with regard to jurisdictional claims in published maps and institutional affiliations. 